\title{
Games of Truth in the Age of Transparency: International Organisations and the Construction of Corruption
}

\author{
Roan Alexander Snyman ${ }^{1}$ D
}

Received: 25 June 2020 / Accepted: 19 August 2021 / Published online: 4 September 2021

(c) The Author(s), under exclusive licence to Springer Nature B.V. 2021

\begin{abstract}
Corruption is one of the most intractable problems that the world is faced with and its reported impact is widespread and pervasive. Since the mid-1990s, international efforts to combat this problem expanded significantly, driven by the involvement governments, international financial institutions and non-governmental organisations. The objective of this article is to use Michel Foucault's work in a critical analysis of the international fight against corruption. This analysis is centred on Foucault's concept of governmentality, as well as his notions of knowledge, power and ethics. The primary focus is on the role played by the World Bank, the International Monetary Fund and Transparency International in the proliferation of international anti-corruption discourse and practices. Furthermore, South Africa will be used as a case study to unpack the historical and contextual factors that play a role in the legitimisation of corruption. As will be shown in this assessment, without adequately understanding the local factors that stimulate corruption and the other societal characteristics that serve to compound its pervasiveness, internationally driven anti-corruption initiatives have limited scope for success. Corruption will persist where there is a lack of resonance between international anti-corruption ideals and local norms, values and ideologies.
\end{abstract}

Keywords Anti-corruption industry · Foucault · International organisations · South Africa

\section{Introduction}

Corruption is a problem that seems intractable. One could say that it knows no state boundaries and that it crosses cultural and social divides. It has been reported that corruption exacerbates inequalities and that it is the poor who bear the brunt of its impact. As a result, there is scarcely any government that is not involved in fighting corruption in one way or another. There are countless organisations, institutions, civil society and religious groups, academics and private sector actors involved in studying corruption and fighting its prevalence (Sampson, 2010). Even though corruption has been a persistent problem throughout history, the international fervour that currently surrounds the fight against corruption is a relatively recent development. The origins of the international anti-corruption movement can be traced back to the 1990s, when a wave of anti-corruption discourse swept over the international scene. Moisés Naím (1995, p. 1) called this

Roan Alexander Snyman

snymanra@gmail.com

1 Department of Philosophy, University of Stellenbosch, Stellenbosch, South Africa the "corruption eruption"; referring not to an increase in the levels of corruption but rather to a marked increase in the attention and discourse centred on corruption.

As the decade progressed, anti-corruption consultancies sprang up, anti-corruption initiatives were implemented, anti-corruption university courses were established and, perhaps most importantly, International Financial Institutions (IFIs) gained interest in corruption and its alleviation (Bukovansky, 2006, pp. 181, 185; Glynn et al., 1997, p. 7; Sampson, 2010, p. 271). It was at this point that the fight against corruption developed into a "... burgeoning industry with hundreds of millions of dollars in project funds, hundreds of anti-corruption professionals and a continuing stream of reports, indicators, conferences, action plans, conventions and evaluations" (Sampson, 2010, p. 271).

One key factor that allowed for this eruption in discourse was the end of the Cold War. Following the collapse of the Soviet Union, post-communist states opened and underwent a process of economic liberation, privatisation and democratisation that revealed the corruption that was prevalent during soviet rule, but also provided new opportunities for corruption (Glynn et al., 1997, p. 10). This turned the global attention toward corruption, and together with the 
engagement of key international organisations and NGOs, created the foundation for the emergence of the international movement against corruption. Since then, this movement has swelled into a global industry with countless programmes and initiatives aimed at fighting the worldwide prevalence of corruption.

It is reported that anti-corruption reforms have not made significant progress in the reduction of corruption despite the increased international focus on corruption. Although it is very difficult to measure the actual success of anti-corruption initiatives, the World Bank recently stated that the corruption scandals over the past few years have been "unprecedented", and that corruption has risen to "levels that many had not considered possible before" (World Bank, 2020a, p. $\mathrm{xv}$ ). According to Transparency International, there is a "staggering number of countries" that are "showing little to no improvement in tackling corruption" (Transparency International, 2020, p. 4).

The purpose of this paper is to use Foucault's concept of governmentality to conduct a critical analysis of international drive to fight corruption. Governmentality will be broken up into a three-pronged analytical framework, consisting of knowledge, disciplinary power and ethics. Firstly, in terms of knowledge, the focus will be on the transformation of corruption into a quantifiable problem of economics during the 1990s and the role played by Transparency International's Corruption Perceptions Index (CPI) in enabling this development. Secondly, the economic quantification of corruption opened the door for anti-corruption to become a disciplinary field of intervention for International Financial Institutions (IFIs) and other international actors. This enabled organisations like the World Bank and the IMF to exert increasing levels of influence and control over the states that they engage with, which often goes beyond fighting corruption alone.

Thirdly, for Foucault the individual subject plays an important role in relation with knowledge and power. The anti-corruption industry is not a homogenous entity that drives global subjectivation and domination - rather there is an interplay between how global discourses and practices are appropriated and implemented locally and how individuals engage, appropriate and in some cases, dismiss international prescripts. "The Ethics of Anti-corruption: The Case of South Africa" section will centre on South Africa as a pertinent case study of how a myriad of contextual and historical factors can play a role in the rationalisation of corruption and thereby limit the effectiveness of international anti-corruption initiatives.

In recent years there have been numerous sharp criticisms against the anti-corruption industry with a growing number of scholars specifically focussing on the involvement of International Financial Institutions (IFIs). The concept of corruption has also come under scrutiny for being overly ambiguous and indeterminate, which has enabled stakeholders to align the concept with their specific goals and ideologies, rather than fighting the problem at hand (Everett et al., 2006, p. 7). According to Pertiwi and Ainsworth (2020) the concept of corruption is assumed to be "stable, clear, universally applicable and self-evident". This assumption has been widely questioned for being business centric and based on western ideologies, norms and values (Bratsis, 2003, p. 17, Brown \& Cloke, 2004, p. 289, De Maria, 2010, p. 117, Pertiwi \& Ainsworth, 2020). Bracking (2007) also follows this line of criticism and argues that the international anti-corruption campaign is centred on the dissemination of Western policies, ideologies and governance structures from the developed to the developing world.

For Pertiwi and Ainsworth (2020), one needs to recognise the constructed meaning of corruption and its varied interpretations within different political and social contexts. Pertiwi and Ainsworth (2020), continues to state that there is a "need for more complex, contextual and historical understandings of the global anti-corruption agenda and its impact on countries labelled as corrupt". This paper enters the space opened by Pertiwi and Ainsworth (2020) and Foucault's work is used to analyse the relation between global anti-corruption discourses and practices and local contexts.

Within the broader literature, Foucault's work and the concept of governmentality has been used before to analyse corruption, notably by Everett et al. (2006) and Polzer (2001). There have also been authors like Baumann (2017, p. 19) that have been critical of the way governmentality is used to assess the global movement against corruption. The argument is made that one needs to go further than just explaining totalised and large-scale forms of power and investigate how these governmental technologies are implemented in practice, and how this relates to the broader political economy (Baumann, 2017, p. 19).

The contribution of this article lies in using Foucault's work to build on the work of these previous authors, but also to highlight that there remains value in applying governmentality in an assessment of the global anti-corruption industry. As mentioned by Baumann (2017), many of the previous studies that made use of Foucault's work focussed primarily on the international dimensions of the anti-corruption industry, while the way in which this global dimension relates to local situations remains largely unexplored. In this study, South Africa will be used as a case study to assess the relation between the global anti-corruption movement and local contextual and historical factors and thereby unpack some of the reasons why international efforts combat corruption may continue to fall short. 


\section{Governmentality and the Fight Against Corruption}

Governmentality is a key concept in Foucault's overall philosophy as well as in his analyses of power (Lemke, 2002 , p. 3). Foucault defines government as the "conduct of conduct" which stretches from self-governance, to the governance of the family, political governance and the governance of the state (2). The term goes further than the contemporary concept of government and refers to "any form of activity that aims to shape, guide, or affect the conduct of some person or persons" (Tremain, 2005, p. 8). Rose and Miller (2010, p. 281) explain that governmentality refers to: "a domain of strategies, techniques and procedures through which different forces seek to render programmes operable, and by means of which a multitude of connections are established between the aspirations of authorities and the activities of individuals and groups".

For the purposes of this study, three key dimensions of Foucault's work will be used as a framework for analysing the governmentality of the anti-corruption industry. Not all these themes were specifically linked to governmentality by Foucault, but it is nonetheless relevant to use these concepts in analytical assessment of the anti-corruption industry. Firstly, what will be important is the role that anti-corruption knowledge played in the emergence of the anti-corruption industry. For Foucault, knowledge is central to the operation of power and is key to the "activities of government and to the very formation of its objects, for government is a domain of cognition, calculation, experimentation and evaluation" (Rose \& Miller, 2010, p. 273). Anti-corruption discourse underwent a significant change in the 1990s as economic analysis became central to the way international actors endeavoured to understand and mitigate corruption. This economic quantification and the role played by Transparency International's Corruption Perceptions Index (CPI) is the focus of "The Construction of Anti-corruption Knowledge" section.

Secondly, Foucault's notion of disciplinary power will be used in the "Anti-corruption as a Method of Control" section to evaluate the way the changes in anti-corruption knowledge opened the door for significant institutional intervention in the fight against corruption. Most notably, the involvement of the World Bank and the IMF increasingly enabled the use of anti-corruption as disciplinary tool, often used to further objectives that go beyond fighting corruption alone. The international fight against corruption is much broader and involves many additional state and non-state actors but focussing on these two organisations will serve as an important reference point of the disciplinary practices of the broader anti-corruption industry.
Governmentality is not just about state power, totalising discourses and disciplinary policies and structures. For Foucault, the manifestation of power in society does not take the form a hegemonic force that dominates and subjugates all in its wake (Dreyfus \& Rabinow, 1983, pp. 184, 192). Individuals play an integral role in their relation to dominant forms of knowledge and disciplinary practices. Foucault (1983, pp. 208,209 ) states that the goal of his work has not specifically been to analyse power, but rather to analyse the different modes through which human beings have been transformed into subjects. Thus, the governmentality of the fight against corruption should not only involve globalised discourses and the practices of power, but also the way these interplay with local perceptions of corruption, local discourses, moralities, policies, ideological perspectives and cultural and historical contextual factors.

Therefore, "The Ethics of Anti-corruption: The Case of South Africa" section is a case study aimed at unpacking the factors that may impact of the prevalence of corruption in a local setting and how ethics, as well as a host of other contextual factors, play a role in preventing the successful implementation of anti-corruption programmes. South Africa is a pertinent cases study, given its immensely complicated history, with a host of different cultural and ideological points of reference. The country had its first democratic election in 1994 after an extended period of institutionalised racial segregation, which was preceded by colonial rule (Southall, 2006, pp. 67, 68; Van Vuuren, 2006, p. 22). South Africa has a "progressive" constitution, with many western institutions and anti-corruption frameworks, but nonetheless has struggled with pervasive corruption (Majila et al., 2014, p. 220; Pityana, 2010). This section will illustrate how a lack of resonance between global anti-corruption ideals and local realities may hamper the effectiveness of international anticorruption initiatives.

\section{The Construction of Anti-corruption Knowledge}

The problem of corruption has been around for a very long time, and its pervasiveness has been prominent throughout history (Buchan \& Hill, 2014, p. 567; Farrales, 2005, p. 4). Academic discussion about the topic proliferated during the 1950s and 1960s when decolonisation brought the problem international attention, and numerous debates raged during the decades that followed about its nature, definition and potential solutions (Bracking, 2007, pp. 8-10; Brown \& Cloke, 2004, p. 280; Farrales, 2005, p. 6).

In the 1990s, however, the field underwent a fundamental change, and one can trace the establishment of what can be called the anti-corruption industry to the mid-1990s (Sampson, 2010). The establishment of the anti-corruption industry and the various factors that contributed to its emergence has already been discussed by several authors, including Glynn 
et al. (1997), Bukovansky (2006) and Sampson (2010). This discussion will not be revisited in this paper, but what is relevant here is a key factor that played a central role in the transformation of anti-corruption discourse: the quantification of corruption as a problem of economics.

The purpose of the discussion here is not to determine whether corruption has economic ramifications, but rather to unpack how the academic studies into its economic impact transformed the way international actors endeavoured to understand and address corruption. Once the connection was made between corruption and economic growth, the discourse centred on corruption increased exponentially. For example, the number of articles in the Financial Times and Economist mentioning corruption increased from an average of 229 per year between 1982 and 1987, to a total of 1246 in 1995 alone (Glynn et al., 1997, p. 21). According to Glynn et al. (1997, p. 7), the “...world-wide backlash against corruption swept like a firestorm across the global political landscape". In the space of a decade, the topic catapulted from the fringes of policy and academic discourse to become one of the most fundamental problems that the world is faced with (Bukovansky, 2006, p. 181).

There are direct parallels that can be drawn between the proliferation of anti-corruption discourse in the 1990s and Foucault's analyses of the emergence of medical discourses centred on sexuality during eighteenth century. According to Foucault $(1976$, pp. 17, 18), at the start of the eighteenth century, there "emerged a political, economic and technical incitement to talk about sex", which Foucault characterised as a "veritable discursive explosion". This went hand in hand with the establishment of a "multiplicity of discourses" which, in turn, produced wide ranging mechanisms, analyses, procedures and policies within different societal and governmental institutions (33).

Behaviour that was previously seen as transgressions of social norms or religious rules were now depicted as symptoms of underlying medical or psychological conditions, perversions or diseases (Dreyfus \& Rabinow, 1983, p. 173). Novel medical conditions emerged as psychologists and academics grappled with newfound problems and anomalies. Psychiatrists discovered conditions such as "mixoscopophiles, gynecomasts, presbyophiles, sexoesthetic inverts, and dyspareunist women" (Foucault, 1976, p. 43). Many of these conditions have long since fallen out of medical knowledge, but at the time, were depicted as very real medical problems diagnosed in accordance with reigning social scientific disciplines and procedures.

These conditions called for the appropriate treatment and were consolidated in reigning medical and institutional practices. For Foucault (1976, p. 25), this was part of a broader drive during the eighteenth century that centred governmental power on the management and administration of populations. The health, welfare and efficiency of the population came to be perceived as the ends of the government of the state, and the proliferation of discourse centred on sex was one part this development (Fimyar, 2008, p. 6). Thus, for Foucault, the phenomenon of sex was constructed during this time period and is a "historical fiction" that serves as a link between the normative practices of power and the biological sciences (Dreyfus \& Rabinow, 1983, p. 179).

Similarly, when it comes to corruption, there was an "eruption" of anti-corruption discourse in the 1990s and corruption quickly became a central issue on the global development agenda (Bukovansky, 2006, p. 181; Naím, 1995, p. 1). Key here was the role played by Transparency International's Corruption Perceptions Index (CPI). The CPI was launched in 1995, by ex-World Bank officials and is an index that ranks the perceived prevalence of corruption in 180 countries globally (Transparency International, 2018).

The CPI does not quantify corruption as such, and it does not report the number of corruption incidents or prosecutions. It does not track the number of bribes paid, or money lost due to governmental mismanagement, nepotism or any other forms of corruption. Rather, the CPI is a standardised international scale through which the perceived levels corruption in different countries is comparatively illustrated (Galtung, 2006, p. 108; Sampson, 2010, p. 274). This perception rating is calculated by combining a range of different polls and surveys, with feedback provided from analysts, business specialists and other commentators (Bukovansky, 2006, p. 193; Transparency International, 2015, p. 1). Countries are then awarded a score of between 0 and 100, with 100 showing low levels of corruption and 0 the highest level of perceived corruption (Transparency International, 2015).

In other words, CPI is not a quantitative representation of the prevalence of corruption, but when CPI was launched in 1995 it introduced, for the first time, a framework that economists could use to determine the economic ramifications of corruption. Once these economic linkages were made there was a flush of new investigations and publications and, as explained by Ivanov (2007, p. 28), economists "seized on such quantifications" to perform "regressions showing that corruption obstructs growth, exacerbates inequality, and expands the unofficial economy".

It was from around 1995 that economists and academics working at, or in association with, the IMF started publishing papers centred on the links between corruption, investment and economic growth (Bukovansky, 2006, p. 189). Ades and Di Tella (1997) discussed the New Economics of Corruption. Mauro (1995) revealed the relation between the prevalence of corruption and economic growth. Tanzi (1995) elaborated on the connection between corruption, governmental practices and financial markets.

Based on the six different corruption perception indices, including the CPI, Gupta et al. (1998, p. 29) conducted a cross-country regression analysis and found that high levels 
of corruption has a negative impact on poverty and income equality by "reducing economic growth, the progressivity of the tax system, the level and effectiveness of social spending, and the formation of human capital". Gupta et al. (1998, p. 29) also argued that corruption has a direct impact on poverty and income inequality by exacerbating unequal educational opportunities and "perpetuating unequal distribution of asset ownership". A World Bank study found that: "lower levels of corruption were seen to be statistically associated with lower levels of income inequality" (Chetwynd et al., 2003, p. 9).

Chetwynd et al. (2003, p. 3) argued that corruption hampers domestic and foreign investment, limits tax income, strains entrepreneurship, negatively impacts infrastructure projects and distorts the "composition of public expenditure". Following the success of the CPI, perception-based indices became central tools in "projecting economic growth, estimating the effectiveness of the government administration, making decisions for strategic investment, and forming international policies" (Shao et al., 2007, p. 157).

Similar to the emergence of medical discourse centred on sex, there was a proliferation of behaviours that could now conceivably fall under the classification of corruption and new forms of corruption were identified, classified, isolated and criminalised (Brown \& Cloke, 2004, p. 277; Caiden et al., 2001; Sampson, 2010, p. 262). The discourse became more formalised and was consolidated with standardised concepts, definitions and remedies (Sampson, 2010, p. 270). As stated by Sampson (2010, pp. 268, 270) a "corpus of key texts" emerged that went together with the proliferation of technocratic definitions, documents and statements driven by an influx of new authors, academics, NGOs and institutions. New areas opened for anti-corruption research, and corruption was revealed to be relevant in the areas of security, healthcare, climate change, sport and education among others (Sampson, 2010, p. 268; Transparency International, 2016).

Significantly, for both corruption and sex, the emergence of a consolidated regime of knowledge occurred following a change in conception. Sex was transformed into a medical phenomenon; a problem concerning social scientific discourse and medical practices. Corruption, on the other hand, changed from being considered as a political problem in the years leading up to the 1990s, into a problem of economics (Polzer, 2001). It was only once this economic connection was empirically illustrated that organisations such as the World Bank and IMF could incorporate anti-corruption measures into their policies and practices (Polzer, 2001, p. $10)$.

Before the 1990s, the World Bank, for example, referred to corruption as the c-word in internal discussions. In 1996, however, the then president of the Bank, James Wolfensohn, stated that the Bank will "redefine the ' $\mathrm{C}$ ' word not as a political issue but as something social and economic" (Ivanov, 2007, p. 31; Polzer, 2001, p. 9). Once corruption was recharacterized in this way, the World Bank's discourse underwent a complete turnaround and by 2006 the Bank was referring to corruption as the "single greatest obstacle to economic and social development" (Bukovansky, 2006, p. 191).

What is important to consider here is not that corruption was a new phenomenon, or that there was a sudden and significant increase in corruption which warranted a consolidated international intervention. It was not that academics and economists were blind to the economic ramifications of corruption before 1990s; rather it was that changes in the anti-corruption discourse allowed for the reformation of the institutional and governmental treatment of corruption. Similarly, the behaviours that scientists and psychologists defined and codified in the eighteenth century were not newly discovered phenomena. It was that new interpretations, definitions, discourses, classifications and medical and psychological treatments were introduced for managing existing behaviours. As such, what was newly discovered were not novel anomalies, but novel interpretations; interpretations that opened the door for significant governmental and institutional intervention.

Foucault (1974, p. 49) states of discourse that it is about the "practices that systematically form the objects of which they speak ... Discourses are not about objects; they do not identify objects, they constitute them and in the practice of doing so conceal their own invention". What Foucault is interested in is the connection between what he sees as the practices of power and the discourses that seek to uncover and reveal truth (Dreyfus \& Rabinow, 1983, p. 177). For Foucault (1975, p. 27), power and knowledge are inseparable. The very revelation of sex as a society-wide medical phenomenon allowed the issue to become enmeshed within the practices of power and therefore subjected to governmental administration and management (Dreyfus \& Rabinow, 1983, p. 178).

Therefore, the emergence of the anti-corruption industry is not about economists finally uncovering the truth about how corruption has a fundamental and empirical linkage to economic growth. Rather, once this connection was made, and once the influential IFIs could enter the field, anti-corruption discourse became, in Foucault's (2008, p. 19) words, "coordinated with a regime of truth". This went hand in hand with the establishment of a set of institutional practices and policies that served to shape the development and legitimisation of an entire industry centred on the fight against corruption.

Thus, the economic quantification of corruption was the governmental technology that played a central role in allowing this field of intervention to come into existence. 
Constructing corruption as a quantifiable economic problem created the perception that a previously hidden problem was now rendered transparent. This construction had a very real impact on the way anti-corruption policies were implemented globally. As the industry emerged; anti-corruption agencies were established, international frameworks and conventions were launched, policies were implemented, and states as well as corporations publicly expressed their zero tolerance for any corrupt behaviour. In short, the actors involved in the industry became free to promote the fight against corruption as a universally applicable, impartial and apolitical project and this allowed organisations such as the World Bank and the IMF to exert increasing levels of influence and control over the countries that they engage with. This is explored further in the following section.

\section{Anti-corruption as a Method of Control}

In his book Discipline and Punish (1975), Foucault investigates how incarceration replaced public torture as the primary method for punishing criminals in Europe during the eighteenth century. In his juxtaposition of torture and incarceration as two different methods of institutional punishment, he does not depict torture as the expression of pure and unadulterated power and it was not "... some uncontrolled act of animal rage" (Dreyfus \& Rabinow, 1983, p. 145). Rather, for Foucault (1975, p. 40) torture was a regulated practice conducted in accordance with the defined and codified legal procedures of the time. What was worth noting for Foucault was how suddenly and almost universally incarceration replaced public torture as the preferred method of punishment (Dreyfus \& Rabinow, 1983, p. 150).

As stated by Foucault (1975, p. 232): “[P]eople were still aware of its novelty; and yet it appeared so bound up and at such a deep level with the very functioning of society that it banished into oblivion all the other punishments the eighteenth-century reformers had imagined. It seemed to have no alternative, as if carried along by the very movement of history". Importantly, for Foucault torture was not the epitome of barbarism and he did not depict the emergence of incarceration as a natural evolution from the horrendous practices of torture to more humane and moral forms of punishment (Dreyfus \& Rabinow, 1983, p. 145). For Foucault, the emergence of incarceration is a manifestation of "practices of disciplining both individuals and populations" (153).

Disciplinary power emerged as part of a technology for governing individual conduct, which is tied to broader socioeconomic changes that occurred during the time (Foucault, 1984, p. 338). Punishment became a "corrective technique" and it was not used to expunge the crime, but rather to "transform the criminal" (Foucault, 1975, p. 127). Importantly, disciplinary power would not be reflected as the infrastructure of the prison and is not a display of strength or dominance (Dreyfus \& Rabinow, 1983, p. 145). As explained by Hindness (1996, p. 113), disciplinary power is "exercised over one or more individuals in order to provide them with particular skills and attributes, to develop their capacity for self-control, to promote their ability to act in concert, to render them amenable to instruction, or to mould their characters in other ways". Disciplinary power refers to the entire milieu of rationalities, policies, practices, codes, procedures and institutional arrangements that served to rationalise and legitimise the institutional existence of incarceration as a governmental practice.

The suggestion here is not that the anti-corruption industry is in some way a descendent of the emergence of incarceration in the eighteenth century. Rather, in terms of the anti-corruption industry, once corruption became an economically quantifiable concept, it opened the possibility for IFIs to use anti-corruption measures as a tool for furthering their influence over the states that they engage with. As stated by Polzer (2001, p. 17), while empirical studies into the economic ramifications of corruption is "presented as a liberation from the uncertainties of politically manipulated perceptions, it is also a new means of control".

Even though the World Bank and the IMF are only one part of the much broader anti-corruption industry, their practices do, however, serve as a good reference point for the disciplinary practices of the broader international fight against corruption. The principal ways that the World Bank and IMF use anti-corruption policies as a method for control are by withholding loans from countries where corruption impacts economic growth and by including numerous specifications related to economic liberalisation in loan agreements (Ivanov, 2007, p. 32). As stated by Rose-Ackerman (1997, p. 103) the World Bank can attempt to control corruption in its projects and loans through advocating reform "....as a condition for receiving bank loans" and it can "... refuse to make new loans and can review old loans".

For example, in 1997 "the IMF suspended a \$220 million loan to Kenya because the government had not done enough to curtail bribery" (Ivanov, 2007, p. 32). In 2012, the World Bank cancelled a $\$ 1.2$ billion loan to Bangladesh, due to concerns that the project has been hampered by corruption (Al-Mahmood, 2012). In its press release about the cancelled loan, the World Bank specifically mentions that it has "credible evidence corroborated by a variety of sources which points to a high-level corruption conspiracy among Bangladeshi government officials" (World Bank, 2012).

When new loans are announced, the conditions often also include strengthening anti-corruption measures within recipient countries. For example, in 2020 the World Bank approved a $\$ 350$ million loan to Ukraine aimed at economic reform, which includes "strengthening Ukraine's anti-corruption institutions" (World Bank, 2020b). In 2019 the World Bank approved a \$750 million loan to Kenya, 
which includes "critical reforms that will enhance competition and market transparency" and "reduce corruption" (World Bank, 2019). Similarly, when the IMF (2019: 2) announced a $\$ 448.6$ million credit facility for the Republic of Congo in 2019, it was stated that the "authorities have implemented an ambitious package of reforms to improve governance", which includes a "newly created anti-corruption commission".

Furthermore, once the World Bank detects that corruption has impacted a project, the companies involved can also be subjected to sanctions. According to Hansen (2012, p. 520) "By 2006, the World Bank had blacklisted more than 330 firms and individuals for having engaged in fraud and corruption in Bank-financed projects". The World Bank can either temporarily or permanently classify companies as ineligible and to be removed from the blacklist, these companies will need to implement specific compliance programmes, which includes sharing additional information with the Bank (520).

The point here is not to question whether IFIs have the right to do whatever they can to ensure that their financial assistance goes where it is intended. Rather it is to highlight the inherently political nature of World Bank and IMF involvement in the anti-corruption industry. By withholding loans or threatening to withdraw financial assistance or blacklisting the companies implicated, the IFIs can exert immense pressure on governments to amend local laws, institutions, as well as political, institutional and business practices, which may often go beyond battling corruption alone.

It is important to note that, both the IMF and World Bank have Articles of Agreement that preclude their involvement in political matters (International Bank of Reconstruction and Development, 2012; International Monetary Fund, 2020). The World Bank specifically states that the "Bank and its officers shall not interfere in the political affairs of any members" and that only "economic considerations shall be relevant" (International Bank of Reconstruction and Development, 2012, p. 10). This non-political commitment is one of the key reasons for the lack of involvement of these organisations in the fight against corruption before the mid1990s. It was only once corruption was recharacterized as a problem of economics that the World Bank and IMF could alter the trajectory of their involvement in the fight against corruption.

In Foucault's view, the introduction of incarceration as the primary method for institutional punishment was not the replacement of an irrational and inherently unethical, barbarous form punishment with a more humane, rational and ethical form of institutional punishment. Rather, incarceration replaced public torture due to the broader societal changes that were happening at the time (Foucault, 1984, p. 338). Both types of punishment were distinctive punitive practices, constituted by specific discourses and disciplines, promoted and propagated by governmental mechanisms aimed at achieving different societal outcomes. Incarceration was only seen as a legitimate form of punitive punishment because it went together with the reformation of the discourse about the rationality of corrective punishment and the role of transforming the criminal as the main objective of institutional punishment.

Similarly, the explosion of anti-corruption discourse in the 1990s was not about the discovery of an enigmatic truth that was hidden from view nor about the emergence of a pioneering industry tasked with fighting a global malice with the aim of bringing about a more ethical international realm. On the contrary, the involvement of the IMF and the World Bank transformed the economic quantification of corruption into a globally relevant disciplinary practice. Where economic quantification justified the existence of a field of intervention centred on corruption-disciplinary practices turned this justification into an institutional reality.

It is important to consider that, for Foucault, discipline is a governmental technique that may ramify through various institutions, but it cannot be reduced to the operation of one specific institution alone (Dreyfus \& Rabinow, 1983, p. 153). In this sense, the World Bank and the IMF are nodes in the dissemination of the relations of disciplinary power. Even though these organisations play a central role in the anti-corruption industry and they use anti-corruption as a method for implementing their policies and programmes, in Foucault's terms, the locus of power does not rest solely in their ambit. The fight against corruption is one component of a broader international disciplinary drive aimed at managing uncertainties, mitigating financial and political risks, as well as instilling a normalised framework of governance globally.

Disciplinary strategies like blacklisting and conditions tied to loan agreements, membership requirements and even just the threat of losing loans, places developing countries in an immensely difficult position. Many of these countries are in dire need of financial assistance and are likely to agree to exhaustive conditions to get access to financial resources. These countries are expected to implement anti-corruption measures aligned to international standards and conventions, which means they are unable to formulate a position on corruption that stands outside the internationally accepted norms. The solutions subsequently implemented are not necessarily aligned to local moralities, political exigencies, or business norms and values, which means anti-corruption measures are rarely nuanced enough to deal with the complexities of local politics and social dynamics. South Africa will serve as a case study in this regard. 


\section{The Ethics of Anti-corruption: The Case of South Africa}

For Foucault, governmentality is not just about totalising discourses and disciplinary power. It is also about the technologies of the self and the role played by individuals. As explained by Tremain $(2005$, p. 8$)$ "As an activity, government can concern one's relation to oneself, interpersonal relations that involve some form of control or guidance, and relations within social institutions and communities, as well as relations concerned with the exercise of political sovereignty". In other words, the governmentality of anti-corruption industry denotes the correlative relationship between anti-corruption knowledge, the disciplinary processes employed by key actors in the industry, as well as the ways individuals orient their own position in this context. Foucault's notion of technologies of the self refers to the methods employed by individuals to adapt their behaviour in accordance with prevailing discourse, moral codes, norms and values (Foucault, 1985, p. 28). More specifically, it refers to the way moral codes are appropriated, how individuals are invited or incited to adjust their behaviour in accordance with such codes and the actual practices they employ in order to become ethical (28).

The objective in this section is to unpack some of the historical and contextual factors that have an impact on the prevalence of corruption in South Africa. South Africa serves as a good case study because of its complicated history, its relatively recent democratisation and its diversity in cultural and ideological characteristics as well as the fact that corruption is currently a central element in the country's public and political discourse. South Africa was subjected to 350 years of colonial rule characterised by dispossession, violence and institutionalised racial discrimination (Southall, 2006, p. 68). In 1912, the Land Act was implemented, which allocated $87 \%$ of South Africa's agricultural land ownership to $13 \%$ of the population (Van Vuuren, 2006, p. 22). The apartheid system ensured that a monopoly of resources and political and economic power rested in the hands of the white minority, which was used to suppress of the rest of the population (Van Vuuren, 2006, p. 2). This established a pattern of inequality that is still highly prevalent today, with South Africa facing a myriad of socio-economic problems, including widespread poverty, inadequate service delivery, high levels of violent crime, corruption, social instability and political upheaval (Ikejiaku, 2009, p. 451).

South African transitioned to democracy in 1994, when the African National Congress (ANC) came into government (Southall, 2006, p. 67). The new South African constitution received international acclaim for its "progressive vision" and its "far-reaching bill of rights" (Pityana, 2010). The constitution ensures protection for freedom of speech for individuals and for the media, and corruption has been a key topic in political and public discourse since transition in 1994 (Hyslop, 2005, p. 773).

South Africa has implemented various anti-corruption initiatives, strategies and polices. Its anti-corruption programme was launched in 1997 and the Public Service AntiCorruption Strategy was adopted in 2002 (Majila et al., 2014, p. 220). The United Nations Convention Against Corruption (UNCAC) was adopted in 2000 and South Africa is also a signatory to a number of other international anti-corruption agreements, including the African Union Convention on Preventing and Combating Corruption, the Southern African Development Community Protocol against Corruption, as well as the Organisation for Economic Co-operation and Development Convention on Combating Bribery of Foreign Public Officials in International Business Transactions (Majila et al., 2014, p. 220; Council for the Advancement of the South African Constitution, 2011, p. 11).

Under these agreements, South Africa has specific obligations to establish an independent anti-corruption agency and to make sure that adequate steps are taken to investigate and prosecute corruption, to raise awareness and educate the public about corruption and to remove opportunities for corrupt behaviour. Additional obligations include, ensuring access to information, encouraging media and civil society to participate in fighting corruption, implementing anti-corruption measures aimed at fighting corruption in the private and public sectors, and cooperating with other states in the investigation and prosecution of corruption (Council for the Advancement of the South African Constitution, 2011, p. 14).

Despite these initiatives and policies, South Africa's public discourse has been dominated by widespread corruption allegations. For example, in the 1990s the former president, Jacob Zuma, was implicated when his close ally, Schabir Shaik, was convicted for corruption, after which the court determined that the relationship between Shaik and Zuma is corrupt (Hyslop, 2005, p. 788). The allegations related to the ZAR43.8bn Arms Deal which involved the procurement of military equipment from several European companies (Southall, 2008, p. 295). The deal was controversial from its inception and 783 charges of corruption were levelled against Zuma, which were ultimately dropped before he became president in 2009 (Southall, 2011, p. 617). Zuma resigned as president in 2018 when the allegations of corruption against him started to build up again (Maritz \& van Rooy, 2021, p. 31). The pressure on Zuma mounted when the Public Protector at the time, Adv Thuli Madonsela, released a report highlighting the improper benefits he received from security upgrades at his private homestead in Nkandla (Maritz \& van Rooy, 2021, p. 31).

Zuma was succeeded by, Cyril Ramaphosa who has also faced some serious allegations, most notably when $34 \mathrm{~min}$ ers were shot and killed by police officers in 2012 while the 
workers were on strike (Beresford, 2015, p. 10). Ramaphosa, who was Vice President at the time, was one of the largest shareholders in the Lonmin Mining Group, and it was alleged that he pressurised police to resolve the situation and take firm action with the striking workers (Beresford, 2015, p. 10). Ramaphosa and other key political figures were later absolved by the Marikana Commission of Inquiry, but these allegations have never completely gone away (Alexander, 2016, pp. 832, 833).

South Africa's private sector has also had its fair share of corruption scandals, with the most notable involving Steinhoff International. Steinhoff is a global retail business selling furniture, consumer electronics, appliances, clothing, beds and mattresses throughout the UK, Europe, African, Australia and New Zealand (Naude et al., 2019, pp. 8, 9). Once the news broke in December 2017 that the CEO, Markus Jooste, resigned due to "accounting irregularities" the company's share price collapsed by more than $85 \%$, which was catastrophic for the company and for investors $(9,10)$. Even though the full details must still emerge, according to Naude et al. $(2019$, p. 2$)$ the Steinhoff scandal was "possibly the biggest case of corporate fraud in South African business history".

These examples illustrate that South Africa has had a history of well documented and reported corruption scandals, despite having significant legislation, policies and initiatives in place. Many authors, such as Manyaka and Nkuna (2014, p. 1574), have argued that the failure in addressing corruption in South Africa is not due to a lack of policy and legislation, but rather due to a lack of enforcement, investigation, prosecution, inadequate oversight mechanisms, low public sector wages and importantly, a lack political will on behalf of government to hold its leaders accountable. There is certainly credence to this argument, but one needs to delve deeper to understand why corruption has been so prevalent in South Africa. The next section is centred on evaluating some of the factors that one needs to consider when assessing corruption in South Africa.

\section{The Governmental Context of Corruption in South Africa}

According to Hyslop (2005, p. 774), most adversaries in South African politics agree that corruption is a problem that needs to be addressed, but if one evaluates their discourses in more detail, it is evident that not everyone agrees on the origin and nature of corruption. In applying the concept of governmentality, it is important to unpack the historical character of corruption in South Africa and shed light on how this has impacted the prevalence of contemporary corruption. There are seven contextual factors that have an impact not only in stimulating corruption South Africa, but also in rationalising engagement in corruption and thereby detract from the effectiveness of any anti-corruption measures.
Firstly, the 1994 election was not a transition between two democratically elected political parties. In 1994, South Africa emerged from a long period of civil strife after which a peaceful transition to democracy was successfully negotiated between an oppressive regime and a revolutionary opposition (Van Vuuren, 2006, p. 13). The fact that this transition was peaceful was a remarkable achievement, but the government that the ANC inherited had to be fundamentally restructured for a democratic South Africa. The institutions, departments, projects and state structures of apartheid South Africa were constructed with the purpose of monitoring, controlling and suppressing most of the South African population. South Africa's intelligence services, for example, operated outside parliamentary oversight or bureaucratic controls, with slush funds for clandestine operations that had little central oversight and no public scrutiny (Hyslop, 2005, p. 784).

The ANC was a revolutionary movement, and the organisation had to reorganise and restructure itself once it was unbanned in 1990 (Beresford, 2015, p. 13). For Hyslop (2005, p. 776), the ANC government faced a dilemma, because the organisation entered government with limited experience of running the administrative system of the country, while the incumbent bureaucracy was from the previous regime and therefore not trusted. This favoured the appointment of political allies, instead of experienced experts from the previous regime or from other political affiliations (776). In other words, there was a dearth of capacity in both the state and in the ANC and therefore the government lacked the capabilities to rein in the emergence of "gatekeepers" who used their government positions to pursue private financial interests (Beresford, 2015, p. 13).

The second factor to consider is that, during the transition process, much of the administrative bureaucracy of the apartheid regime was embedded within new state structures, including homeland administrations already affected by corruption. The apartheid state required a massive bureaucracy with many parallel and duplicate structures to administer its policies and to keep adversaries in check (Van Vuuren, 2006, p. 41). The government had departments to manage the affairs of the Caucasian population, in addition to three parallel structures to manage the affairs of the other South African population groups (41). This massive and complicated bureaucratic structure was inherited by the new South Africa and much of the previous homeland administrations were imbedded into the new provincial structures, which may have simply transferred corruption from the previous administration into new state structures (Lodge, 1997, p. 5).

Thirdly, the transition to democracy did not include dealing with past financial crimes and corruption. For the old regime to cede power there were certain issues that were "too politically sensitive" to be addressed directly (Van Vuuren, 2006, p. 13). The transition was a compromise 
between political opponents and the stalemate was overcome by the establishment of the Truth and Reconciliation Commission (TRC) $(15,16)$. The TRC's mandate was to bear witness to human rights violations during the apartheid era and offer reparation and rehabilitation to the victims. Importantly, corruption was outside the mandate of the commission and the financial crimes of the apartheid era were not directly addressed (Carranza, 2008, p. 313). This means that many individuals who benefitted from past financial injustices were never held accountable.

The fourth factor is that, even if corruption was included in the mandate of the TRC, a massive amount of information was destroyed before transition, which made it very difficult to trace and uncover the corruption of the past. It is reported that the South African Police, the Security and Military Intelligence Sector, the Homeland bureaucracies, the Department of Defence, the State Security Council as well as the Presidency all took part in the destruction and disposal of documents (Van Vuuren, 2006, p. 14). This means that potential evidence of corruption was destroyed along with evidence of countless other abuses that happened during the apartheid era.

The fifth factor is that the ANC has ideological and organisational ideals that do not necessarily correspond with neoliberal notions of corruption. As stated by Chipkin (2013, pp. 215, 216), the ANC does not have "a liberal conception of politics and of the state". Bruce (2014, p. 57) echoes this position and explains that the prevalence of corruption serves to highlight that many of the ANC and government officials do not endorse the South African constitution in its entirety, which is simply "one of a number of moral and intellectual points of reference". Another important value for the ANC is organisational loyalty, which is, according to Hyslop (2005, p. 783), a "value that transcends all others". This value was embedded in the new government, which has made it difficult for the ANC to denounce corruption and patronage within its own ranks (Hyslop, 2005, p. 783).

The sixth factor is the poverty and significant income disparity between different population groups in South Africa. After more than two and a half decades of democracy, a big proportion of the population is still facing serious social and economic challenges. It is estimated that unemployment stands at $60 \%$ for the previously disadvantaged communities in South Africa, with the official unemployment rate at $27.7 \%$ (du Toit et al., 2018, p. 122). For Lodge (1997, p. 18), after transition the South African government was very vulnerable to corruption due to the absorption of a new political class that has recently experienced extreme poverty and oppression.

According to Chipkin (2013, p. 221), the new political class did not have any historical wealth or assets and lifting the living standard of so many people would have always been an immensely difficult task for any new government.
For many South Africans, becoming involved in patron-client networks was the only way to access services, opportunities and resources for their families and for navigating the "the harsh realities of unemployment, poverty and inequality" (Beresford, 2015, pp. 13, 14). In other words, the state is seen as the primary and a legitimate way to overcome poverty and to attain and generate wealth and therefore political connections come at a premium (Southall, 2006, p. 80).

The seventh factor is that current policies aimed at redistribution of wealth and economic restitution may have contributed to the legitimisation of corruption. The South African government has implemented wide ranging Black Economic Empowerment (BEE) policies aimed at redressing the inequalities that was embedded into the South African society by the apartheid regime (Ponte et al., 2007, p. 2). These BEE policies have come under criticism and is one of the government's more controversial policies (20). There is general acknowledgement in South Africa that economic transformation policies are necessary to address the injustices of the past, but critics have argued that BEE has created a "small but remarkably wealthy ANC-connected empowerment elite" (Southall, 2006, p. 68). The argument is made that these policies have only served to enrich those with connections to the government and has not had a notable impact on the widespread poverty in South Africa (Ponte et al., 2007, p. 2).

This has created the situation where BEE policies may be seen as ineffective by one part of the population and simultaneously as unfair and discriminatory by another. In this context corruption can be rationalised because of the disadvantages still suffered by black South Africans and may be "tacitly accepted by many within the elite as a means to reverse historic racist inequities" (Bruce, 2014, p. 57). Many public officials do not see corruption and broader development goals as mutually exclusive (57). For Southall (2006, p. 80), political shortcuts can be perceived as morally justifiable, and aligned to addressing racial imbalances, even if these shortcuts are illegal. Similarly, Chipkin (2013, p. 219) states that corruption can be justified as aligned to the long-term ideal of creating a "black middle and capitalist class". On the other side, a possible lack of opportunities for employment, education and in business might lead some white South Africans to feel "unfairly disadvantaged by affirmative action" and thereby serve to rationalise their own engagement in corruption (Bruce, 2014, p. 57).

This is where the discussion links back with governmentality and Foucault's work. South Africa recently accepted a loan from the IMF to cope with the impact of the Covid-19 pandemic. It has been reported that President Ramaphosa provided assurance that "anti-corruption measures would be set up to deal with criminals eyeing the Covid-19 funds is what convinced the International Monetary Fund to give SA a R70-billion ( $\$ 4.3$ billion) Covid-19 emergency assistance 
loan" (Sowetan Live, 2020). Furthermore, the IMF senior representative in South Africa, Montfort Mlachila, stated that the IMF supports the president's announcement to "intensify anti-corruption actions" and that the government has "put in place preventive measures to ensure that the procurement of supplies and services is transparent, competitive and cost-effective" (Sowetan Live, 2020).

While there is no doubt that most South Africans would want to ensure that these funds go where intended, one nonetheless needs to delve into the nature of the engagement between the IMF and SA, specifically when it comes to corruption and governance reform. Many of these such reforms may have an impact on corruption, but their effectiveness is hampered due to the lack of resonance between international ideals and local realities. As stated previously, for Foucault, individuals do not simply accept rules, norms, values and moral codes in a passive way. Individuals play an active role in grappling with, accepting and in some cases rejecting the norms and values that they are confronted with (Foucault, 1985, p. 28). The global anti-corruption campaign depicts anti-corruption as a moral imperative, but there is insufficient consideration given to how individuals are expected to incorporate these prescripts into their own moral frameworks, given the complexity of the contextual factors as discussed above.

What needs to be considered here is the role that ethics and morality plays both in the legitimisation of the anticorruption industry, but also in the way individuals justify their own engagement in corruption. For Chipkin (2013, pp. $223,224)$, the idea that corruption proliferates due to a lack of ethics overlooks the fact that morality is often used to legitimise corrupt behaviour. Public officials in South Africa will often accept that their behaviour is unprocedural, but this is justified on a moral basis due to the unfairness and inequality that persists in the South African economy (223). Chipkin (2013, pp. 223, 224) continues: "public servants often insist that they are corrupt in order to be moral or, at least, to restore the moral balance". For Beresford (2015, pp. $13,14)$, normative critiques of corruption fail to understand that corruption proliferates, not due to a moral deficiency, but rather due to socioeconomic factors.

If one considers the poverty and income inequality that persists in South Africa and also the historical injustices and oppression suffered under the apartheid regime, the continued racism and discrimination that is still prevalent in South African society today, the lack of redress for apartheid financial crimes, organisational bureaucratic complexity as well as a diversity in ideological, cultural and political perspectives it becomes very difficult to envision how individuals are expected to proactively grapple with international anticorruption prescriptions in order to override their already entrenched ethical standpoints. These contextual factors coalesce to create a climate where corruption can actively be rationalised, and importantly, justified by the individuals involved on personal moral grounds.

This points toward a deficiency in the ethics of the fight against corruption. The international actors involved often explicitly proclaim the ethical importance of eradicating the "cancer" of corruption, but because the concept is depicted as a universally relevant, politically neutral, technocratic, economic term, little consideration is given to the linkages between anti-corruption prescriptions and personal ethics. Furthermore, little consideration is given to how corruption may relate to different cultural and societal dynamics and the complex historical character of engagement between different communities and social groups, especially in diverse countries like South Africa.

International actors certainly allude to systemic corruption where corruption may be embedded within business and societal norms, but for these attestations to be meaningful they need to be accompanied by a more in-depth evaluation of the historical and contextual factors as well as the moral justifications that enable the rationalisation of corruption. In this regard one can make use of Foucault's ethical framework to highlight some key questions that need to be addressed by primary actors involved in the anti-corruption industry.

For Foucault, individual ethics is characterised by four main aspects, which include the ethical substance, the mode of subjection, the self-forming activity, and the "telos" of moral behaviour (Foucault, 1984, pp. 352-355). The first aspect relates to the type of behaviour that is under consideration. In terms of corruption, what type of behaviour is the anti-corruption industry focussed on? If one relates this to the general definition of corruption, the abuse of entrusted/ public power for private gain, is the fight against corruption centred on solidifying the sanctity of the public versus the private sphere? Or is anti-corruption focussed on improving the ethicality of economic interactions in general? Is it focussed on ensuring adherence to financial laws and regulations? Is it focussed on the failure to overcome innate desires of greed and self-enrichment? Or is it a combination of all these things? If it is focussed on greed, where does one draw the line between legitimate greed an illegitimate greed and who draws this line?

Secondly, the mode of subjection refers to how individuals are obligated to transform themselves to become ethical subjects (Foucault, 1984, pp. 352-355). In terms of the anti-corruption industry, how are individuals invited and/or incited to see their behaviour as moral or immoral within a specific societal setting? In a South African context, what type of moral prescript about corruption will be enough to supersede the injustice felt by an individual who has been impacted by historical oppression and racial injustice? Importantly, would it be feasible to expect this ethical ideal to override other socio-economic demands and pressures 
related to poverty, income inequality, discrimination and diverse ideological and cultural beliefs?

Thirdly, what practices can individuals follow, not only to comply with anti-corruption rules, but also to believe in the ethics as espoused by the international fight against corruption? This is what Foucault (1984, pp. 352-355) calls the self-forming activity. How do individuals relate to the rules imposed on them through anti-corruption? Are these simply seen as rules to follow or are they embraced as ethical prescripts? How does this resonate with personal ethics and local community values and cultural ideals?

Finally, what type of person does one aspire to become by acting ethically in this context? Foucault refers to this as the "telos" of moral behaviour (Foucault, 1984, pp. 352-355). For an individual, what is the ultimate objective of adhering to anti-corruption rules? The goals and justifications for corruption can include overcoming poverty, gaining access to resources and services, providing for one's extended family, redressing past financial exploitation, addressing racial inequities as well as many other potential justifications. In fighting corruption, what would success look like for an individual, for a country and for the anti-corruption industry as a whole?

For South Africa, would the end goal be linked to historical and contextual complexities? Would this be economic and racial equality between population groups? Is it about achieving economic emancipation and justice and restitution for past economic grievances and exploitations? If corruption, as attested by Transparency International (2021), is "everywhere", "anywhere", "hidden in the shadows" and always adapting "to different contexts"; how would one ever know that it has been eradicated? Would the end goal be holding power accountable for the "common good", which is Transparency International's 2030 goal (Transparency International, 2021)? Or is the objective rather "ending extreme poverty", as stated by World Bank (2021)? Is it about eradicating systemic corruption for the sake of "macroeconomic stability" as stated by the IMF (2018)?

There are no straight-forward answers these questions, and therefore anti-corruption activists need to delve deeper into the ethical and moral foundation upon which the international fight against corruption is based. This goes far beyond acknowledgement that corruption is entrenched or systemic and should involve more than mere emotive proclamations about the moral imperative of fighting the cancer of corruption. The organisations involved in the anti-corruption industry must unpack, precisely, what the ethics is of fight against corruption and how individuals and communities should work towards incorporating this into their own ethical frameworks.

While there is little doubt that corruption has an economic impact, this does not mean that the factors that create and sustain its prevalence only respond to economic interventions. The quantification of corruption as a problem of economics enabled the fight against corruption to become an internationally driven field of intervention centred on eradicating a globally relevant problem. This enabled organisations like the World Bank and the IMF depict their involvement as neutral, value free, non-political, while the solutions proposed by these organisations are inherently political. As discussed above, it is precisely at this point where international anti-corruption ideals may be insufficient in providing the ethical framework to override already entrenched ethical perspectives. Corruption is a complex reflection of a diverse array of different global and local societal dynamics, and any anti-corruption intervention will need to recognise and develop programmes that can respond effectively to this complexity.

\section{Conclusion}

The objective of this article was to make use of Foucault's work in a critical analysis of the international anti-corruption industry. By applying the concept of governmentality, it is evident that international anti-corruption knowledge serves to justify and perpetuate the policies and practices of the anti-corruption industry. The World Bank and the IMF are key actors in this industry, but these organisations are not one-dimensional hegemonic actors blindly driving the global implementation of neoliberal policies. Rather, these organisations are complex and characterised by internal flux, policy changes and developments in the global political economy. The fight against corruption is one component of a broader international disciplinary drive aimed at managing uncertainties, mitigating risks and instilling a normalised framework of governance globally. Importantly, anti-corruption discourse allows the international actors involved in the industry to depict their involvement as neutral, value free, non-political and motivated by fighting a universal problem, while in reality, the solutions proposed by these organisations are inherently political and ideological. The problem is that the ideological objectives that permeate the anti-corruption industry is obfuscated, blurred and hidden under layers of technocratic discourse.

Ultimately, corruption persists not due to a dearth in morality. The very acceptance and rationalisation of corruption are tied to a myriad of historical and societal factors, one key component of which is its justification by individuals on moral grounds. To override this justification, the international actors involved in fighting corruption need to do more than simply acknowledge that this moral complexity exists. In terms of Foucault's ethical framework, for the fight against corruption to be successful, it needs to resonate with individuals, and they need to have the freedom to develop their own ethical justifications for defining corruption, and 
importantly, for fighting corruption within their communities, companies and governments.

Acknowledgements Firstly, I would like to thank my supervisor who guided me through the completion of my masters as well as well as this article, Dr. Minka Woermann. Thank you for your patience and constructive feedback. I would also like to thank the Kocks Foundation for the financial support provided for the completion of my Master's degree as well as my wife, Mandi Snyman.

Funding The author received a Grant from the Kocks Foundation, covering a portion of the funding requirements for the completion of his master's thesis, which formed the basis of this article.

\section{Declarations}

Conflict of interest The author declares that there is no conflict of interest.

Ethical Approval This article was a qualitative desktop-based research article and ethics approval was not required.

\section{References}

Ades, A., \& Di Tella, R. (1997). The new economics of corruption: A survey and some new results. Political Studies, 45, 496-515.

Alexander, P. (2016). Marikana Commission of Inquiry: From narratives towards history. Journal of Southern African Studies, 42(5), $815-839$

Al-Mahmood, S. (2012). World Bank Cancels \$1.2 Billion Bangladesh Loan [Online]. http://www.wsj.com/articles/SB1000142405270 2303561504577498363128959728 [2016, September 15].

Baumann, H. (2017). A failure of governmentality: Why Transparency International underestimated corruption in Ben Ali's Tunisia. Third World Quarterly, 38(2), 467-482.

Beresford, A. (2015). Power, patronage, and gatekeeper politics in South Africa. African Affairs, 114(445), 226-248.

Bracking, S. (Ed.). (2007). Corruption and development. Palgrave Macmillan.

Bratsis, P. (2003). The construction of corruption. Social Text, 21(4), 9-33.

Brown, E., \& Cloke, J. (2004). Neoliberal reform, governance and corruption in the South: Assessing the international anti-corruption crusade. Antipode, 36(2), 272-294.

Bruce, D. (2014). Control, discipline and punish: Addressing corruption in South Africa. South African Crime Quarterly, 48, 49-62.

Buchan, B., \& Hill, L. (2014). An intellectual history of political corruption. Palgrave Macmillan.

Bukovansky, M. (2006). The hollowness of anti-corruption discourse. Review of International Political Economy, 13(2), 181-209.

Caiden, E. G., Dwivedi, P. O. \& Jabbra, J. (eds.). (2001). Where corruption lives. Bloomfield: Kumarian Press.

Carranza, R. (2008). Plunder and pain: Should transitional justice engage with corruption and economic crimes? International Journal of Transitional Justice, 2(3), 310-330.

Council for the Advancement of the South African Constitution. (2011). Corruption: Towards a Comprehensive Societal Response [Online]. http://www.casac.org.za/wpcontent/uploads/2011/03/ corruptionfullreport.pdf [2020, January 7].
Chetwynd, E., Chetwynd, F., \& Spector, B. (2003). Corruption and poverty: A review of recent literature. Management Systems International.

Chipkin, I. (2013). Whither the state? Corruption, institutions and state-building in South Africa. Politikon, 40(2), 211-231.

De Maria, W. (2010). The failure of the African anti-corruption effort: Lessons for managers. International Journal of Management, 27(1), 117-120.

Dreyfus, H., \& Rabinow, P. (1983). Michel Foucault: Beyond structuralism and hermeneutics. University of Chicago Press.

Du Toit, M., De Witte, H., Rothmann, S., \& Van den Broeck, A. (2018). Unemployment experiences in context: A phenomenological study in two townships in South Africa. Journal of Psychology in Africa, 28(2), 122-127.

Everett, J., Neu, D., \& Rahaman, A. S. (2006). The global fight against corruption: A Foucaultian, virtues-ethics framing. Journal of Business Ethics, 65, 1-12.

Farrales, M. J. (2005). What is corruption: A history of corruption studies and the great definitions debate. University of California.

Fimyar, O. (2008). Using governmentality as a conceptual tool in education policy research. Educate, 1, 3-8.

Foucault, M. (1974). The archaeology of knowledge. Travistock.

Foucault, M. (1975). Discipline and punish: The birth of the prison. Random House.

Foucault, M. (1976). The will to knowledge: The history of sexuality (Vol. 1). Penguin Books.

Foucault, M. (1983). The subject and power. In H. Dreyfus \& P. Rabinow (Eds.), Michel Foucault: Beyond structuralism and hermeneutics (pp. 208-226). University of Chicago Press.

Foucault, M. (1984). The Foucault Reader: An introduction to Foucault's thought. Penguin Books.

Foucault, M. (1985). The use of pleasure: The history of sexuality (Vol. 2). Vintage Books.

Foucault, M. (2008). The birth of biopolitics: Lectures at the college de France. London: Palgrave Macmillan.

Galtung, F. (2006). Measuring the immeasurable: Boundaries and functions of macro corruption indices. In C. Samford, A. Shacklock, \& C. Connors (Eds.), Measuring corruption. Ashgate.

Glynn, P., Kobrin, S. J., \& Naím, M. (1997). The globalization of corruption. In K. A. Elliott (Ed.), Corruption and the global economy. Institute for International Economics.

Gupta, S., Davoodi, H., \& Alonso-Terme, R. (1998). Does corruption affect income inequality and poverty? Economics of Governance, $3,23-45$

Hansen, H. (2012). The power of performance indices in the global politics of anti-corruption. Journal of International Relations and Development, 15(4), 506-531.

Hindess, B. (1996). Discourses of power. Blackwell.

Hyslop, J. (2005). Political corruption: Before and after apartheid. Journal of Southern African Studies, 31(4), 773-789.

Ikejiaku, B. (2009). Crime, poverty, political corruption and conflict in apartheid and post apartheid South Africa: The implications on economic development. African Journal of Political Science and International Relations, 3, 451-459.

International Bank for Reconstruction and Development. (2012). Articles of Agreement [Online]. https://thedocs.worldbank.org/en/doc/ 722361541184234501-0330022018/original/IBRDArticlesOfA greementEnglish.pdf [2021, July 16].

International Monetary Fund. (2018). Peeling back the many layers of corruption [Online]. https://www.imf.org/external/pubs/ft/ar/ 2018/eng/spotlight/reducing-corruption/ [2021, January 15].

International Monetary Fund. (2019). Republic of Congo: IMF Country Report No. 19/244.

International Monetary Fund. (2020). Articles of Agreement [Online]. https://www.imf.org/external/pubs/ft/aa/pdf/aa.pdf [2021, July $16]$. 
Ivanov, K. (2007). The limits of a global campaign against corruption. In S. Bracking (Ed.), Corruption and development: The anti-corruption campaigns. Palgrave Macmillan.

Lemke, T. (2002). Foucault governmentality and critique. Rethinking Marxism, 14(3), 49-64. https://doi.org/10.1080/0893569021 01242288

Lodge, T. (1997). Political corruption in South Africa. African Affairs, 97(387), 157-187.

Majila, T., Derek Taylor, J., \& Raga, K. (2014). A comparative analysis of the implementation of anti-corruption legislation by anticorruption agencies in the provinces of the Eastern and Northern Cape. The Journal for Transdisciplinary Research in Southern Africa, 10(1), 22. https://doi.org/10.4102/td.v10i1.21.

Manyaka, R., \& Nkuna, N. (2014). The phenomenon of corruption in the South African public sector: Challenges and opportunities. Mediterranean Journal of Social Sciences, 5(27), 1572-1580.

Maritz, A., \& van Rooy, B. (2021). Linking the dots: Metaphors in the narrative of self-justification by former President Zuma. Language Matters, 52(1), 30-49.

Mauro, P. (1995). Corruption and growth. Quarterly Journal of Economics, 110(3), 681-712.

Naím, M. (1995). The corruption eruption. Brown Journal of World Affairs, 2(2), 234-261.

Naude, P., Hamilton, B., Ungerer, M., Malan, \& D., de Klerk, M. (2019). Business perspectives of the Steinhoff Saga. University of Stellenbosch Business School.

Pertiwi, K. \& Ainsworth, S. (2020). Democracy is the cure? Evolving constructions of corruption in Indonesia 1994-2014. Journal of Business Ethics. https://doi.org/10.1007/s10551-020-04560-y

Pityana, S. (2010). Strong Civil Society: A condition for good governance, address to the Inyathelo Conference, 15 November 2010.

Polzer, T. (2001). Corruption: Deconstructing the World Bank Discourse. Development Studies Institute Working Paper No. 01-18. London: London School of Economics.

Ponte, S., Roberts, S., \& van Sittert, L. (2007). To BEE or not to BEE? Black economic empowerment, business and the state in South Africa. Development and Change, 38(5), 933-955.

Rose-Ackerman, S. (1997). The role of the World Bank in controlling corruption. Faculty Scholarship Series. Paper 591.

Rose, N., \& Miller, P. (2010). Political power beyond the State: Problematics of government. The British Journal of Sociology, 61, 271-303.

Sampson, S. (2010). The anti-corruption industry: From movement to institution. Global Crime, 11(2), 261-278.

Shao, J., Plamen, I., Podobnik, B., \& Stanley, E. (2007). Quantitative relations between corruption and economic factors. The European Physical Journal, B(56), 157-166.

Southall, R. (2006). Ten propositions about black economic empowerment in South Africa. Review of African Political Economy, $111,67-84$.

Southall, R. (2008). The ANC for sale? Money, morality \& business in South Africa. Review of African Political Economy, 35(116), 281-299.

Southall, R. (2011). Family and favour at the court of Jacob Zuma. Review of African Political Economy, 38(130), 617-626.

Sowetan Live. (2020). We were persuaded by President Cyril Ramaphosa's anti-graft stance: IMF [Online]. https://www. sowetanlive.co.za/news/south-africa/2020-07-30-we-were-persu aded-by-president-cyril-ramaphosas-anti-graft-stance-imf/ [2021, August 2]

Tanzi, V. (1995). Corruption, governmental activities, and markets. Finance and Development, 32(4), 24-26.

Transparency International. (2015). Corruption Perceptions Index 2015: Technical Methodology Note [Online]. https://www.trans parency.it/wp-content/uploads/2016/01/Technical-MethodologyNote-Corruption-Perceptions-Index-2015.pdf [2016, March 3].

Transparency International. (2016). Corruption Perceptions Index [Online]. http://www.transparency.org/cpi2015\#results-table [2016, May 21].

Transparency International. (2018). Corruption Perceptions Index [Online]. https://www.transparency.org/cpi2018 [2019, August 30].

Transparency International. (2020). Corruption Perceptions Index 2019 [Online]. https://images.transparencycdn.org/images/2019_CPI_ Report_EN.pdf [2020, October 15].

Transparency International. (2021). What is Corruption [Online]. https://www.transparency.org/en/what-is-corruption [2021, January 10$]$.

Tremain, S. (2005). Foucault, governmentality, and critical disability theory: An introduction. University of Michigan Press.

Van Vuuren, H. (2006). Apartheid Grand Corruption Assessing the scale of crimes of profit in South Africa from 1976 to 1994. Institute for Security Studies.

World Bank. (2012). World Bank Statement on Padma Bridge [Online]. https://www.worldbank.org/en/news/press-release/2012/06/29/ world-bank-statement-padma-bridge [2021, January 15].

World Bank. (2019). World Bank approves $\$ 750$ Million for Kenya in support of reforms in agriculture, housing, digital technology and fiscal management [Online]. https://www.worldbank.org/en/news/ press-release/2019/05/28/world-bank-approves-750-million-forkenya-in-support-of-reforms-in-agriculture-housing-digital-techn ology-and-fiscal-management [2021, January 17].

World Bank. (2020a). Enhancing Government Effectiveness and Transparency: The Fight Against Corruption [Online]. https://docum ents1.worldbank.org/curated/en/235541600116631094/pdf/Enhan cing-Government-Effectiveness-and-Transparency-The-FightAgainst-Corruption.pdf [2021, January 10].

World Bank. (2020b). World Bank Approves \$350 Million Loan to Support Reforms for Economic Recovery in Ukraine [Online]. https://www.worldbank.org/en/news/press-release/2020/06/26/ world-bank-approves-350-million-loan-to-support-reforms-foreconomic-recovery-in-ukraine [2021, Feb 2].

World Bank. (2021). Combating corruption [Online]. https://www. worldbank.org/en/topic/governance/brief/anti-corruption [2021, January 12].

Publisher's Note Springer Nature remains neutral with regard to jurisdictional claims in published maps and institutional affiliations. 